\section{Seismic evidences for salt tectonics in Camamu-Almada Basin}

\author{
Brandão, A. G.; Vidigal-Souza, P. A. D.; Holz, M.
}

Copyright 2019, SBGf - Sociedade Brasileira de Geofísica

This paper was prepared for presentation during the $16^{\text {th }}$ International Congress of the Brazilian Geophysical Society held in Rio de Janeiro, Brazil, 19-22 August 2019.

Contents of this paper were reviewed by the Technical Committee of the $16^{\text {th }}$ International Congress of the Brazilian Geophysical Society and do not necessarily represent any position of the SBGf, its officers or members. Electronic reproduction or storage of any part of this paper for commercial purposes without the written consent of the Brazilian Geophysical Society is prohibited.

\begin{abstract}
There are several tectono-sedimentary similarities in the evolution of the Brazilian east margin basins, but there are many basins that need more study, such as the Camamu-Almada Basin, especially in deep water areas. In the study area, the presented work mapped two fault systems. A first one, associated to the distensive regime of margin passive basin and responsible for the division of the transitional sequence in different domains: the siliciclastic (NW) and the saline domain (SE). And the second, related to the salt movement. In these regions, the lateral and vertical movement of the evaporitic rocks may have favored the migration of hydrocarbons, creating preferential flow directions, as well as deforming the overlapping layers, creating diverse structures that propitiate the accumulation of hydrocarbons.
\end{abstract}

\section{Introduction}

Historically, the hydrocarbon exploration in the CamamuAlmada Basin began in the 1960s with the drilling of two terrestrial wells. Currently, according to data of May of 2015 from the National Agency for Petroleum, Natural Gas and Biofuels (ANP), a hundred and twenty wells have been drilled; the basin produces daily $503 \mathrm{bbl}$ of oil, $5,850 \mathrm{Mm}^{3}$ natural gas, in three fields located predominantly in shallow water; and, has approximately 38.4 MMbbl of oil and 17,949 $\mathrm{MMm}^{3}$ of Gas (proven reserves).

The study area corresponds to a polygon located in the center-southern portion of the Camamu-Almada Basin, offshore the State of Bahia, Brazil. The Barra Fault System and the Itapuã Fault System separate it from the Recôncavo Basin on the north and the Olivença High separates it from the Jequitinhonha Basin on the south (Figure 1A). Figure 1B shows the basin's main lithostratigraphic units, their respective ages and their tectonic context. The main objective of this work is to present a seismic stratigraphic interpretation focusing on the evaporitic rocks, which have been poorly studied before in this particular area, relating the main features and structures with sedimentary basins situated in the same geotectonic context, and searching for possible plays.
The formation of the Brazilian east margin basins occurred during the break-up of the paleocontinent Western Gondwana with a rifting process that initiated during the Late Jurassic/Early Cretaceous (145Ma), that was followed by a clockwise rotation of South America relative to Africa (Szatmari and Milani, 2016). This rotation implied in the early development of the basins located in the southern segment of the Atlantic Margin, while the northern ones developed relatively late, as proposed in several models (e.g., Matos, 1992).

The development of the South Atlantic margin occurred through four tectonic phases: pre-rift, rift, transitional (Early Aptian/Very Early Albian) and drift. The transitional phase marks the decrease of the crustal stretching rate and the lack of intense tectonic activities that, added to the evaporation of invading seawater, caused the deposition of evaporites over the rift strata, forming a huge regional salt deposit (Hay et al., 2006). The depositional process lasted approximately 1 million years with salt occurrences over the South Atlantic Margin, both in Brazil and West Africa (Cainelli and Mohriak, 1999). According to Szatmari and Milani (2016), the thickness and width of the evaporite deposits increase southward mainly due to the relative rotation mentioned above.

In the Camamu-Almada Basin the evaporites are associated with the Igrapiúna member of the Taipus Mirim Formation, with expressive volumes in the deep-water region, and minor occurrences in the shelf region. The salt deposits are verified in drill cuttings of wells situated in the study area and are represented by layers of halite, anhydrite and, in minor proportions, tachyhydrite.

\section{Method}

The database used for this study is composed of twelve wells and fifty 2D seismic lines and were provided by ANP (National Agency of Petroleum). The softwares used in this work were Seisee, Schlumberger Log ToolBox, IHS Kingdom, OpendTect to Analyse, Edit, load and interpret Well and Seismic Data.

The seismic interpretation follows the stratigraphic concepts and lithostratigraphic classification proposed by Holz et. al (2007) and Gontijo et. al (2007), respectively. Synthetic seismograms were constrained using sonic log to tie seismic and well data. 

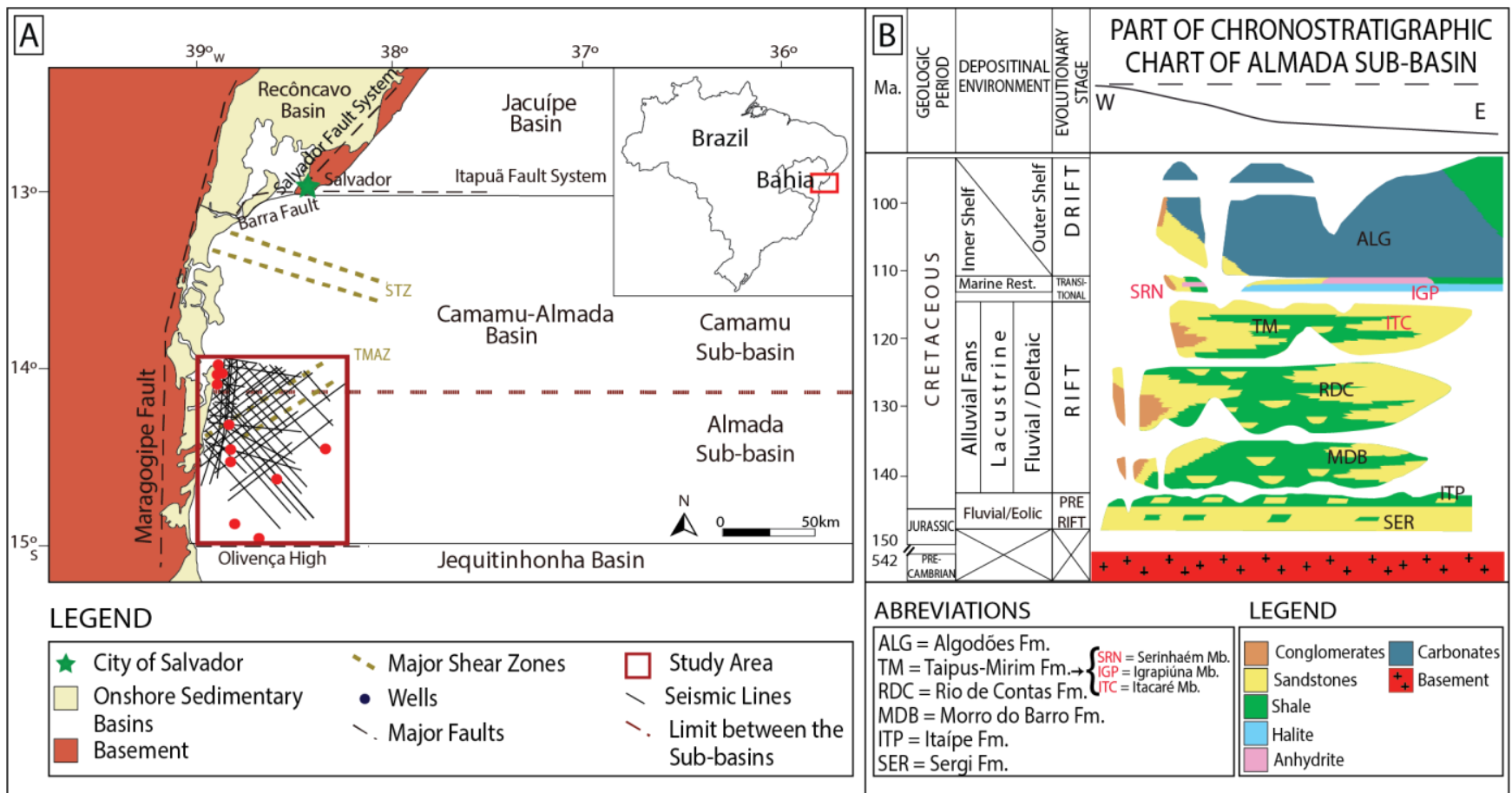

Figure 1 - Location of the Camamu-Almada Basin, the study area and their main structural features. Part of the chronostratigraphic chart of the Almada Sub-basin (Gontijo et. al, 2007).

\section{Interpretation Analysis}

The seismic interpretation follows the stratigraphic concepts and lithostratigraphic classification proposed by Holz et. al (2007) and Gontijo et. al (2007), respectively. Figure 2 shows a seismic section illustrating the stratigraphic sequence and the main horizons interpreted in this work: the post-rift unconformity, and the break-up unconformity. In the following paragraphs, there is a description of the seismic imaging and the lithological characteristics of the complete sedimentary sequence studied.

The lowest boundary of the transitional sequence, the post-rift unconformity, named by some studies (e.g. Cruz, 2008) as the Pre Alagoas Superior Unconformity, is correlated to an expressive event of base level lowering that marks the beginning of the predominance of thermal subsidence in the Camamu-Almada Basin, according to Dias (2005). In the seismic lines, this horizon consists of an irregular low-amplitude reflector overlapped by numerous truncations, behaving as an angular unconformity. On the other hand, in the well data, this horizon commonly marks the transition of siliciclastic deposits to the first occurrences of evaporate minerals or, in fewer examples, the transition of fluvial-lacustrine green/gray shales to white/red shales in well cuts.

The upper boundary, the breakup unconformity, mostly coincides with the first continuous strata above the lowamplitude high-deformed reflectors associated with evidence of halokinesis and consequently, salt structures. In the stratigraphical analysis of the wells, this horizon marks the transition of the salt to carbonates and shales correlated with the Algodões formation of the drift succession. Where there wasn't evidence of evaporites, the study utilized the transition of siliciclastic to carbonate deposits. Negative variations of the gamma-ray well logs, indicating a base level lowering, sustain the chosen criteria of both unconformities demarcation.

The transitional sequence, named as K50, was deposited at the late Neo-Aptian, in a proximal marine ambient, with a restricted circulation of water and in arid conditions (Gontijo et. al, 2007). In the shallow proximal area, siliciclastic intervals with minor occurrences of anhydrite and carbonates are more abundant, whereas, in the distal region, salt predominates. At this area, the salt is arranged, on the well core, in the form of intercalations of halite, anhydrite and, in minor proportions, tachyhydrite. This disposal suggests the occurrence of events of cyclic deposition.

The Lithostratigraphic classification correlates the siliciclastic deposits with the Serinhaém member, whereas the salt deposits with the Igrapiúna member; both of the Taipus-Mirim Formation.In the seismic imaging, this sequence varies between 80 to $200 \mathrm{~ms}$ twoway travel time thick at the proximal regions where it can be correlated with parallel, high-amplitude, low-frequency, and continuous reflections. However, the thickness of the sequence increases eastward through the deep-water area, where salt inflation structures are observed - such as anticlinals, pillows, and diapirs. At this region, K50 is associated with chaotic, low amplitude sismofacies. Figure 3 denotes the numerous normal faults and the deformed strata associated with the salt movement and accumulation. This study also mapped isolated secondary depocenters, the mini-basins. Post-Albian strata, of the drift phase, filled those depocenters. 

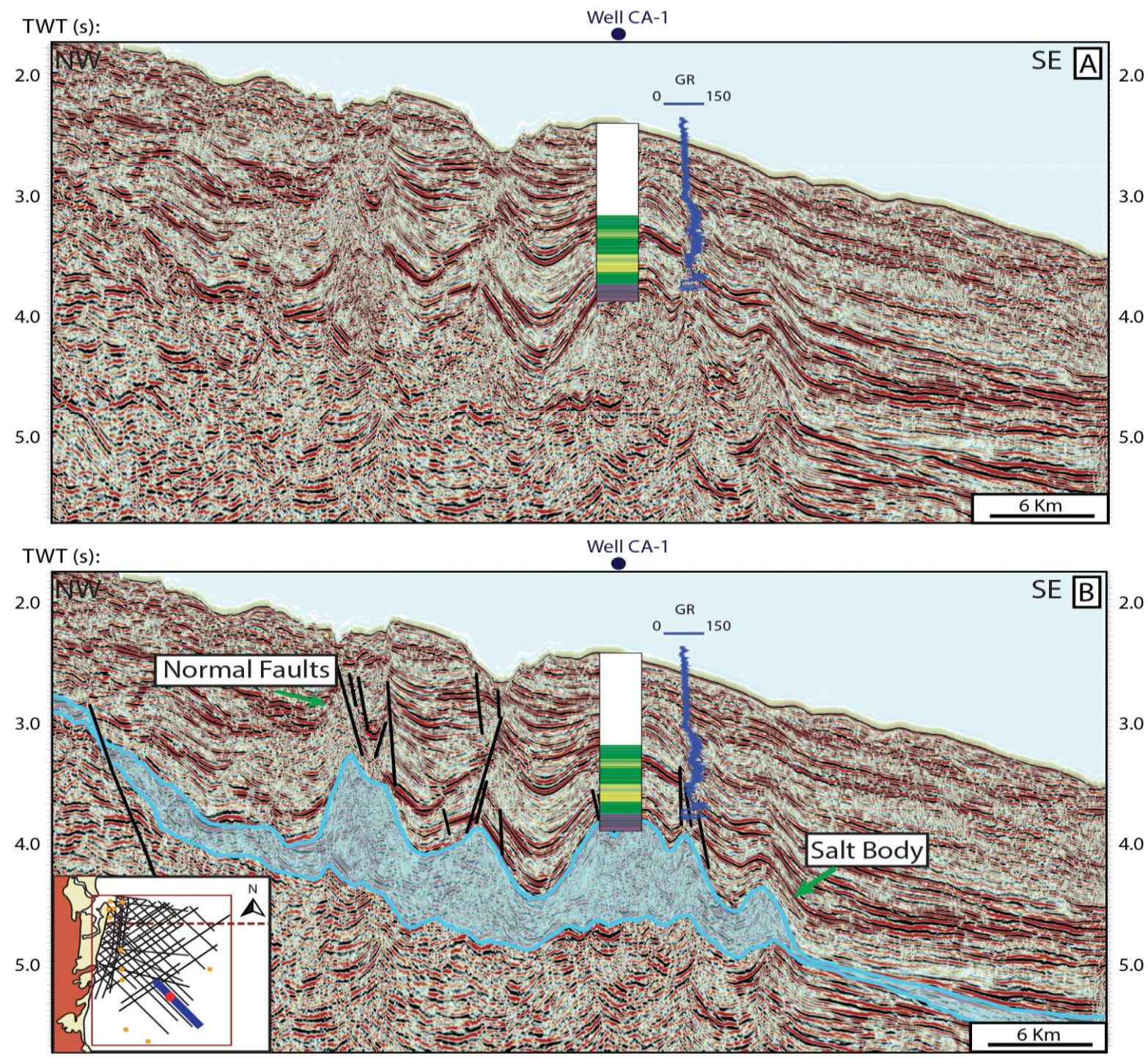

Figure 2 (A) Non-interpreted representative seismic section of the study area, (B) interpreted representative seismic section of the study area correlated with the Well CA-1 that reaches the salt body, including lithology and gamma-ray data, and enhancing an expressive salt body and the normal faults associated with the halokinesis.

\section{Results}

In the seismic sections, mainly in the deep water region, the correlation with the well data shows that the evaporites are commonly associated with a chaotic sismofacies, series of normal faults, and numerous onlap terminations indicated by nearby curved reflectors (Figure 2).

The interpreted faults fit in the extensional tectonic salt models (Jackson, 1995). It explains the association of distensive movements to faults that affect sedimentary overload and generate a series of saline features as salt pillows and diapirs. Figures 3 and 4 show NW faults separating thin layers to salt pillows and diapirs. The fault separates the sequence K50 into two different domains: The siliciclastic and the salt domain.

The lateral flow of salt is often accompanied by the formation of salt pillows and diapirs (Mohriak \& Szatmari, 2009). Due to its geographical location (slope) and progradational context until the Eocene (Gontijo et al., 2007) the salt flowed and formed those structures. 

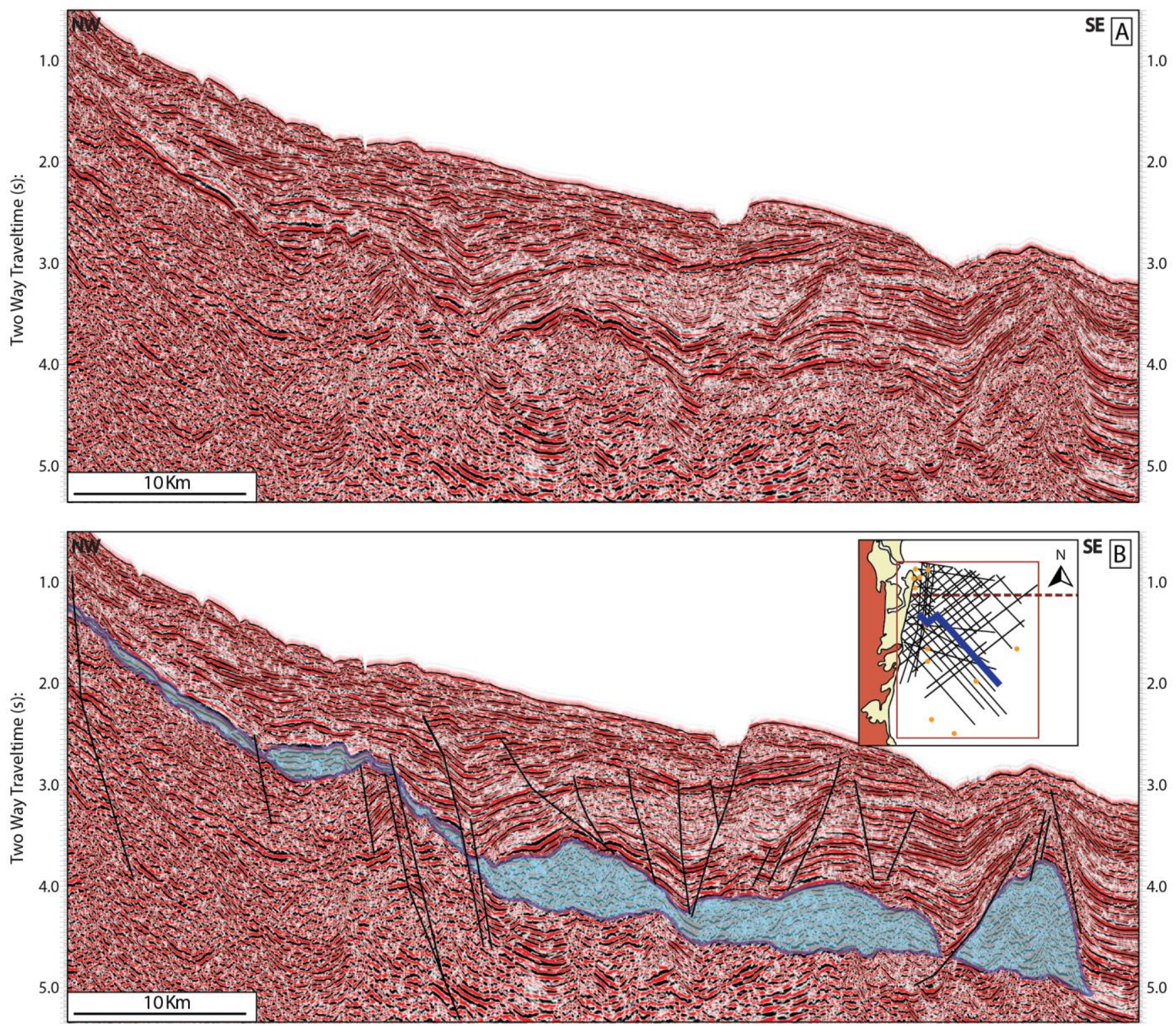

Figure 3: (A) Non-interpreted representative seismic section of the study area, (B) interpreted representative seismic section of the study area showing the main faults and the two domains of the transitional sequence: The siliciclastic (NW) and the saline domain (SE).

Folded sedimentary layers over the salt, evidentiate that the saline structures developed syntectonically to those depositions.

The seismostratigraphic interpretation led to the creation of a seismic time isopach map for the evaporite deposits in the study area (Figure 5).

The cited map illustrates the thickening of the evaporites from the proximal to the distal regions and from the north to the south portion of the study area. According to Ferreira et al. (2009), this might occur due to gravitational flow of the salt controlled by the structural features of the basement inherited from the rift phase of the basin. In the proximal region, the salts present a maximum thickness of $30 \mathrm{~ms}$. In the distal zone there are areas displaying salt inflation, indicated by expressive structures like domes, cannopies and diapers up to 1200 ms thick. However, even in these areas the presence of mini-basins (suggesting salt deflation) can be detected. 

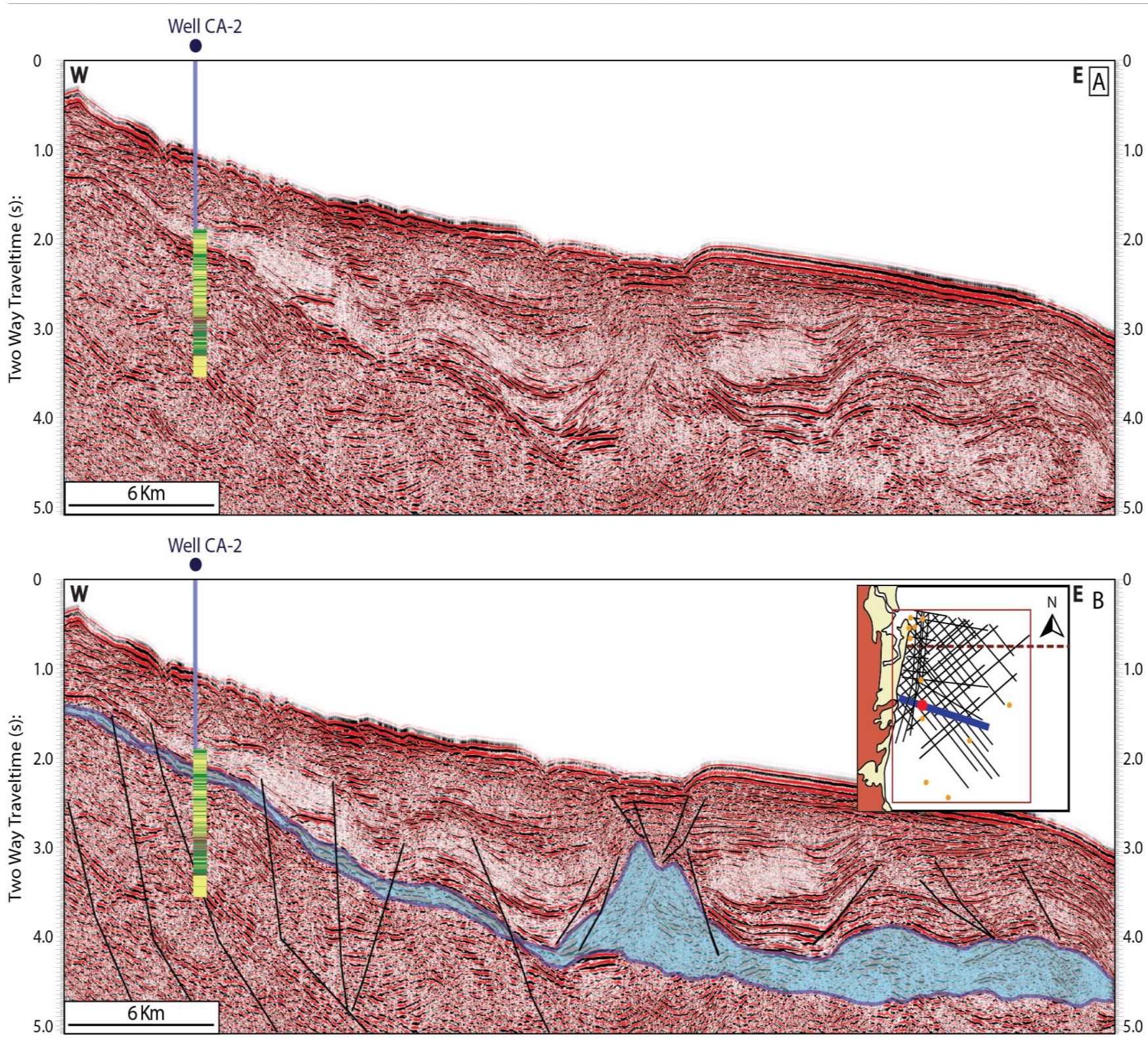

Figure 4: (A) Non-interpreted representative seismic section of the study area, (B) interpreted representative seismic section of the study area showing that the Well CA-2 does not presente salt in its composition, only silicilastic sediments. 


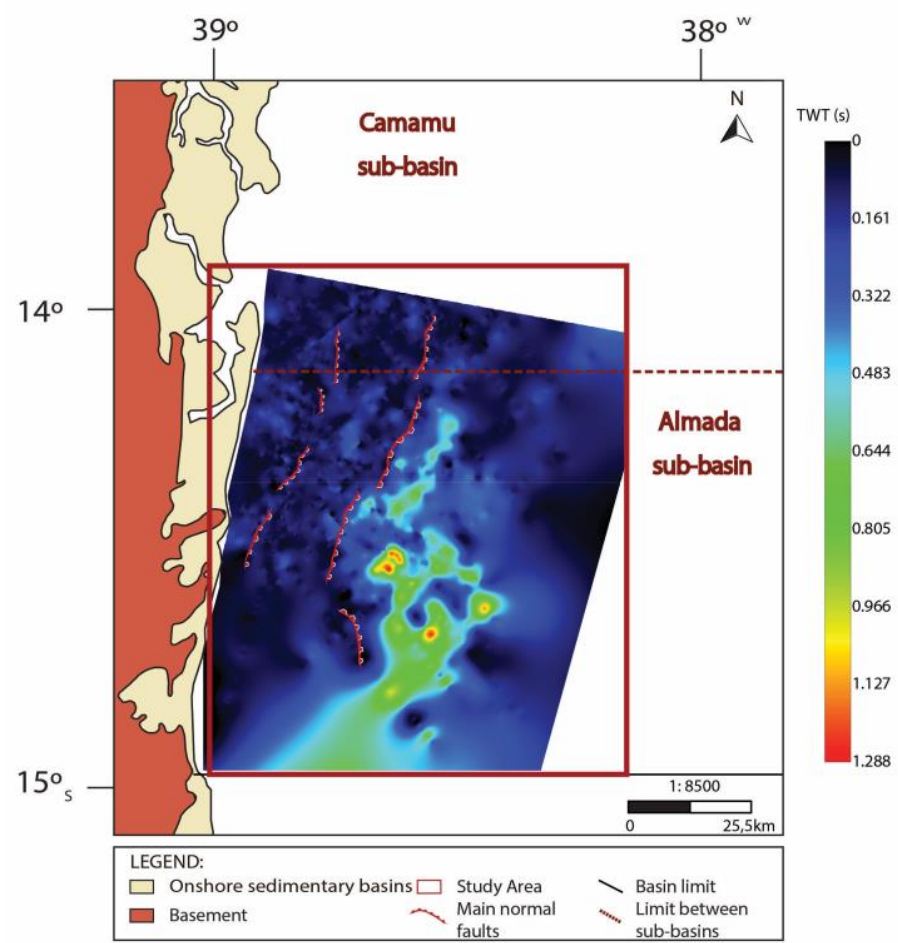

Figure 5: Seismic time isopach map of the salt body in the study area generated from the seismic stratigraphic interpretation. Note that in the proximal region, the salts present a maximum thickness of $30 \mathrm{~ms}$ (dark blue color), while in the distal area they are zones of salt inflation, indicated by the green, yellow and red colors. The arrows indicate the presence of mini-basins (salt deflation) within the zone of inflation.

\section{Conclusions}

Confronting the general idea of only minor evaporate deposits in the basins of the northeastern Atlantic margin of Brazil and the aforementioned southward thickening of the evaporite deposits, this research has shown the existence of a significant salt body in the south of the Camamu-Almada basin, which may directly influence new hydrocarbon exploration leads for the basin. According to the seismic interpretation, this deposit is extremely deformed, marking salt deflation and salt inflation zones, directly associated with diapirs and mini-basins respectively. This research also suggests that the salt deformation mentioned may have acted creating two main types of hydrocarbon traps in the study area

\section{Acknowledgments}

We thank CNPq / INCT-GP / FAPESP / ANP and FINEP (GASBRAS Project) for their support; IHS Markit for the IHS Kingdom Software license, dGB Earth Sciences for the OpendTect software license and GETA / LAGEP / CPGG for enabling its physical facilities used for the production of the article.

\section{References}

Cainelli, C., Mohriak, W.U. [1999] Some remarks on the evolution of sedimentary basins along the eastern Brazilian continental margin. 22, 206-216. In: Calassou, S., Moretti, I., [2003] Sedimentary flattening and multiextensional deformation along the West African margin. Marine and Petroleum Geology, 20, 71-82.

Chang, H., Assine, M., Corrêa, F., Tinen, J., Vidal, A., Koike, L. [2008] Sistemas petrolíferos e modelos de acumulação de hidrocarbonetos na Bacia de Santos. Revista Brasileira de Geociências, 38, 29-46.

Ferreira, T.; Caixeta, J., Lima, D. [2009] Controle do embasamento do rifteamento das bacias de camamu e almada, Boletim de Geociências da Petrobrás, 17, 69-88.

Gontijo, G., Dupuy, I., Milhomem, P., Caixeta, J., Menezes, P. [2007] Bacia de Almada. Boletim de Geociências da Petrobrás, 15(2), 463-473.

Hay, W.W., Migdisov, A., Balukhovsky, A., Wold, C.N., Floegel, S., Soeding, E. [2006] Evaporites and the salinity of the ocean during the Phanerozoic: implications for climate, ocean circulation and life. Palaeogeography, Palaeoclimatology, Palaeoecology. 240, 3-46.

Matos, R.M.D. [1992] The Northeastern Brazilian Rift System. Tectonics, 11, 766-791.

Szatmari, P., Milani, E.J. [2016] Tectonic control of the oilrich large igneous-carbonate-salt province of the South Atlantic rift. Marine and Petroleum Geology, 77, 567-596. 